\title{
Evidence for Compensatory Photosynthetic and Yield Response of Soybeans to Aphid Herbivory
}

\author{
Christopher J. Kucharik, Amelia C. Mork, \\ Timothy D. Meehan, Shawn P. Serbin, \\ Aditya Singh, Philip A. Townsend, \\ Kaitlin Stack Whitney, Claudio Gratton
}

Accepted for publication in Journal of Economic Entomology

April 2016

Environmental \& Climate Science Dept.

Brookhaven National Laboratory

\author{
U.S. Department of Energy \\ USDOE Office of Science (SC), \\ Basic Energy Sciences (BES) (SC-22)
}

\footnotetext{
Notice: This manuscript has been authored by employees of Brookhaven Science Associates, LLC under Contract No. DE-SC0012704 with the U.S. Department of Energy. The publisher by accepting the manuscript for publication acknowledges that the United States Government retains a non-exclusive, paid-up, irrevocable, world-wide license to publish or reproduce the published form of this manuscript, or allow others to do so, for United States Government purposes.
} 


\section{DISCLAIMER}

This report was prepared as an account of work sponsored by an agency of the United States Government. Neither the United States Government nor any agency thereof, nor any of their employees, nor any of their contractors, subcontractors, or their employees, makes any warranty, express or implied, or assumes any legal liability or responsibility for the accuracy, completeness, or any third party's use or the results of such use of any information, apparatus, product, or process disclosed, or represents that its use would not infringe privately owned rights. Reference herein to any specific commercial product, process, or service by trade name, trademark, manufacturer, or otherwise, does not necessarily constitute or imply its endorsement, recommendation, or favoring by the United States Government or any agency thereof or its contractors or subcontractors. The views and opinions of authors expressed herein do not necessarily state or reflect those of the United States Government or any agency thereof. 


\title{
Evidence for Compensatory Photosynthetic and Yield Response of Soybeans to Aphid Herbivory
}

\author{
Christopher J. Kucharik, ${ }^{1,2,3}$ Amelia C. Mork, ${ }^{1}$ Timothy D. Meehan, ${ }^{4}$ Shawn P. Serbin, ${ }^{5}$ \\ Aditya Singh, ${ }^{6}$ Philip A. Townsend, ${ }^{6}$ Kaitlin Stack Whitney, ${ }^{4}$ Claudio Gratton, ${ }^{4}$
}

\begin{abstract}
1Department of Agronomy, University of Wisconsin-Madison, 1575 Linden Dr., Madison, WI 53706 (kucharik@wisc.edu; amelia. perillo@gmail.com), ${ }^{2}$ Nelson Institute Center for Sustainability and the Global Environment (SAGE), University of WisconsinMadison, 1710 University Avenue, Madison, WI 53726, ${ }^{3}$ Corresponding author, e-mail: kucharik@wisc.edu, ${ }^{4}$ Department of Entomology, University of Wisconsin-Madison, 1552 University Av., Madison, WI 53706 (tmeeha@gmail.com; whitney3@wisc.edu; cgratton@wisc.edu), ${ }^{5}$ Brookhaven National Laboratory, Biological, Environmental \& Climate Sciences Department, Bldg., 490D - P.0. Box 5000, Upton, NY 11973-5000 (sserbin@bnl.gov), and ${ }^{6}$ Department of Forest and Wildlife Ecology, University of Wisconsin-Madison, 1630 Linden Dr., Madison, WI 53706 (singh22@wisc.edu; ptownsend@wisc.edu)
\end{abstract}

\begin{abstract}
The soybean aphid, Aphis glycines Matsumura, an exotic species in North America that has been detected in 21 U.S. states and Canada, is a major pest for soybean that can reduce maximum photosynthetic capacity and yields. Our existing knowledge is based on relatively few studies that do not span a wide variety of environmental conditions, and often focus on relatively high and damaging population pressure. We examined the effects of varied populations and duration of soybean aphids on soybean photosynthetic rates and yield in two experiments. In a 2011 field study, we found that plants with low cumulative aphid days (CAD, less than 2,300) had higher yields than plants not experiencing significant aphid pressure, suggesting a compensatory growth response to low aphid pressure. This response did not hold at higher CAD, and yields declined. In a 2013 controlled-environment greenhouse study, soybean plants were well-watered and fertilized with nitrogen (N), and aphid populations were manipulated to reach moderate to high levels $(8,000-50,000 \mathrm{CAD})$. Plants tolerated these population levels when aphids were introduced during the vegetative or reproductive phenological stages of the plant, showing no significant reduction in yield. Leaf $\mathrm{N}$ concentration and CAD were positively and significantly correlated with increasing ambient photosynthetic rates. Our findings suggest that, given the right environmental conditions, modern soybean plants can withstand higher aphid pressure than previously assumed. Moreover, soybean plants also responded positively through a compensatory photosynthetic effect to moderate population pressure, contributing to stable or increased yield.
\end{abstract}

Key words: plant-insect interaction, photosynthesis, yield, leaf gas exchange, host plant resistance

The soybean aphid (Aphis glycines Matsumura) is the key pest of soybean (Glycine max L.) in North America and the first to consistently cause soybean yield loss (Ragsdale et al. 2004, Hartman et al. 2011). Outbreaks of soybean aphids in North America can reduce plant height, pods per plant, seeds per pod, individual seed weight, photosynthetic rates, and, subsequently, yields (Macedo et al. 2003, Ragsdale et al. 2007, Beckendorf et al. 2008). Currently, it is widely accepted that a regimen of insecticide treatments is necessary when soybean aphid populations reach 250 individuals per plant and are expected to increase (McCarville et al. 2011). This management response is consistent with Ragsdale et al. (2007), who reported an average economic threshold of 273 aphids per plant, and described a linear 6.9 percent yield reduction for every 10,000 cumulative aphid days (CAD). Other studies have shown that the negative effects of soybean aphid feeding occur at levels other than 250 aphids plant $^{-1}$, or not at all (Riedell and Catangui 2006). Furthermore, soybean plants are reported to be most susceptible to soybean aphids that establish in the vegetative stages through reduction of seedpod formation (Rhainds et al. 2007, Beckendorf et al. 2008). While the consensus of previous research is that high soybean aphid pressure generally leads to yield reductions, actual yield losses are manifested through the timing of introduction, aphid density, and environmental conditions (e.g., weather and soil water and nutrients), all of which contribute to plant physiological response.

Currently, there is an incomplete understanding of how soybean aphids affect plant physiology under widely varying environmental conditions and a wide range of $\mathrm{CAD}$, which makes it difficult to ascertain the mechanisms that contribute to yield loss, or, alternatively, to soybean growth tolerance to aphid pressure (Pierson et al. 2011). Understanding plant physiological response is key in global 
change studies because ecological modeling tools that adopt a semimechanistic approach to simulating plant photosynthesis and response to environmental drivers (Kucharik 2003) need to account for feedbacks between pest pressure and plant physiological responses when applied across larger spatial scales.

Two previous studies have shown that there can be reductions in soybean photosynthetic capacity with soybean aphid feeding (Macedo et al. 2003, Pierson et al. 2011). Macedo et al. (2003) reported a 50 percent reduction in photosynthetic capacity with low (20 per leaflet) aphid densities on plants, but no change in photoelectron transport. However, they only measured gas exchange on a single day in late August two months after planting, and did not report other environmental variables during the experiment, such as leaf temperature, leaf percent nitrogen $(\mathrm{N})$, or available soil moisture, although these are presumed to have been consistent among their plants given the experimental design. Pierson et al. (2011) collected leaf gas exchange data across four soybean genotypes and identified one genotype (Asgrow 2703) that exhibited significant reductions in photosynthetic capacity at 29 days after aphid introduction based on typical photosynthetic $\mathrm{CO}_{2}(\mathrm{~A}-\mathrm{Ci})$ response curves.

Other research suggests that crops such as wheat and soybean can have physiological and growth tolerance to aphids (Haile et al. 1999; Pierson et al. 2010, 2011; Prochaska et al. 2013), potentially through compensatory effects attributed to responding to herbivory (Nowak and Caldwell 1984, Trumble et al. 1993). Furthermore, there are several soybean cultivars that have reported moderate tolerance to soybean aphids (Pierson et al. 2010, 2011), whereby the yield loss was lower than expected based on the previous work of Ragsdale et al. (2007). In addition, soybean plant resistance is connected to Rag1 (Kim and Diers 2009) and Rag2 (Mian et al. 2008) genes in the soybean germplasm, whereby cultivars reduce aphid development without negatively impacting yield. While reductions in soybean yield at high aphid populations ( $>10,000 \mathrm{CAD})$ have been shown consistently across multiple studies in cultivars that do not have Rag1 or Rag2 genes (Ragsdale et al. 2007, Rhainds et al. 2007, Beckendorf et al. 2008), there are fewer studies on the effects of low-to-moderate $(<10,000 \mathrm{CAD})$ soybean aphid populations, or under nonstressed growing conditions such as plentiful water and N, on soybean yield. For example, Liere et al. (2015) observed a positive relationship between soybean aphid abundance and yield at low pest densities ( $<100$ aphids per plant), suggesting some degree of overcompensation. Furthermore, a study of $\mathrm{N}$ isotope fractionation in green peach aphid herbivore-host plant systems (Brassica oleracea var. capitata and Arabidopsis served as the host plants) suggested that plant responses to aphids could be partially controlled by $\mathrm{N}$ cycling and $\mathrm{N}$ availability (Wilson et al. 2011).

To further explore the impacts of aphid pressures on soybean yields and photosynthetic activity across a variety of environmental conditions, we conducted a field study in 2011 in southern Wisconsin and a greenhouse study in 2013. We studied the effects of differing aphid pressure, measured in CAD, and the impacts of plentiful water and $\mathrm{N}$ on soybean yield and photosynthetic rates in cultivars that do not have a known soybean aphid resistance. Our research addressed the following questions: 1) What is the overall relationship between soybean aphids and soybean yield and photosynthesis for a wide range of CAD? 2) Is there evidence for soybean compensatory growth response when experiencing low-to-moderate aphid pressure $(<10,000 \mathrm{CAD})$ ? 3) Are soybean plants able to tolerate increased aphid pressure when experiencing increased delivery of water and N? 4) Does the timing of aphid introduction (vegetative vs. reproductive stage) significantly impact soybean yields and photosynthetic rates?

\section{Materials and Methods}

\section{Study System}

This study was conducted in a soybean field in southern Wisconsin during July and August in 2011 and in an environmentally controlled greenhouse during June-August in 2013. Soybean plants were subjected to varying levels of pest pressure through the introduction of soybean aphids. Soybean aphids, native to Asia, were first detected in Wisconsin in 2000 and have since been found in 21 U.S. states and Canada (Venette and Ragsdale 2004). The soybean aphid is heteroecious holocyclic, meaning that it alternates between a primary and secondary host, and reproduces both sexually and asexually at different points during the growing season. With reduced photoperiod and temperature near the end of the growing season in temperate regions, winged females (gynoparae) travel to common buckthorn (Rhamnus cathartica L.), its primary (and overwintering) host. In the spring, winged soybean aphids move to the secondary host, the soybean (Ragsdale et al. 2004).

Soybean aphid populations can double in as little as $3 \mathrm{~d}$ in the field, leading to severe plant damage in a brief time (Ragsdale et al. 2007). Soybean aphid feeding results in excreted honeydew, which builds up and promotes sooty mold growth on leaves, further reducing photosynthesis (Peterson and Higley 1993). In addition, soybean aphids can indirectly reduce yields by acting as a vector for plant diseases such as the soybean, cucumber, and alfalfa mosaic virus (Clark and Perry 2002, Davis et al. 2005).

In 2011, a paired study (i.e., soybean grown inside and outside of insect exclusion cages) was designed to quantify the relationships between CAD and soybean yield, harvest index, and leaf photosynthesis under typical field conditions. In 2013, a greenhouse experiment introduced soybean aphids at variable aphid densities onto plants under low water and $\mathrm{N}$ stress conditions at two different growth stages (V2 and R0) to create a gradient in soybean growth and yield. These phenological stages of soybean-vegetative stage V2 (two sets of unfolded trifoliate leaves) and reproductive stage R0 (beginning flowering)—correspond to periods when aphids typically start to build in significant numbers, resulting in plant photosynthetic and yield responses (Fehr et al. 1971).

\section{Field Experiment}

Field measurements were performed at the University of WisconsinMadison's Arlington Agricultural Research Station (Arlington, WI, $\left.43.33^{\circ} \mathrm{N}, 89.33^{\circ} \mathrm{W}\right)$. Soils at this site are classified as Plano silt loams (fine-silty, mixed, superactive, mesic typic Argiudolls), which are highly productive soils formed under the former Empire Prairie and part of the North American Prairie-Savanna ecotone before it was converted to agricultural land use in the mid-1800s. For 19812010 , mean annual air temperature was $6.8^{\circ} \mathrm{C}$ and mean annual precipitation was $869 \mathrm{~mm}$. The region typically receives $324 \mathrm{~mm}$ of precipitation during summer (June-August), with an average air temperature of $17.5^{\circ} \mathrm{C}$ (NOAA 2011). The average air temperature during the summer of 2011 was significantly above $\left(+3.2^{\circ} \mathrm{C}\right)$ the climatological average, and only 43 percent of normal summer precipitation was received. August of $2011(38.4 \mathrm{~mm})$ was a particularly dry period and contributed to extensive water stress in the region. The growing degree days (base $10^{\circ} \mathrm{C}$ ) accumulated in 2011 were $1299^{\circ} \mathrm{C}$, which was slightly higher than the long-term (1981-2010) average of $1260^{\circ} \mathrm{C}$.

The paired cage/noncaged experiment was established on 12 May 2011 on a 1.6-ha field that was chisel-plowed and cultivated before planting. The field received $39 \mathrm{~kg} \mathrm{ha}^{-1} \mathrm{~N}, 44 \mathrm{~kg} \mathrm{ha}^{-1}$ phosphorus, and $120 \mathrm{~kg} \mathrm{ha}^{-1}$ potassium from manure applied after 
harvest in fall 2010. No organic or inorganic fertilizer was applied in 2011, and irrigation was not used. Untreated soybean variety 'Dairyland 2011RR' (Dairyland Seed, West Bend, WI) was planted on 31 May 2011 at a rate of $72.8 \mathrm{~kg}$ seed ha ${ }^{-1}\left(65 \mathrm{lbs}_{\mathrm{bcre}}^{-1}\right)$ and a depth of $3.8 \mathrm{~cm}$ (1.5 in) with $19-\mathrm{cm}(7.5$-in) row spacing. Plants were sprayed on July 7 with Roundup ${ }^{\circledR}$ PowerMAX (Monsanto, St. Louis, MO) at a rate of 1.75 liters ha ${ }^{-1}\left(24 \mathrm{oz} \mathrm{acre}^{-1}\right)$.

Insect cages (Lumite Inc., Alto, GA) with dimensions of 2 by 2 by $2 \mathrm{~m}$ (length $\times$ width $\times$ height) and a $32 \times 32$ mesh size $(0.5$ by $0.5 \mathrm{~mm}$ ) were used to maintain control over aphid populations and to exclude the influence of aphid natural enemies. Twelve insect cages were erected on 13 June 2011 when soybean plants were at development stage V0, and remained in place until harvest occurred. Insect cages were positioned in two parallel rows of six cages each, approximately $6 \mathrm{~m}$ apart, with individual cages spaced $3 \mathrm{~m}$ apart. During installation, soil was tilled around the perimeter of insect cages to allow mesh material to be buried approximately $30 \mathrm{~cm}$ belowground, which served as a physical barrier to outside plant encroachment and for added cage stability. Mowing of weeds to a height of approximately $10 \mathrm{~cm}$ around insect cages took place in early August, and weeds were periodically hand-pulled from around the perimeter of each cage plot and within the cages as needed. Twelve additional 2-by 2-m open-air study plots were established in an adjacent part of the experimental field with the same arrangement.

\section{Aphid Populations}

Open and caged study plots were used to examine the impact of varied soybean aphid densities, measured as CAD (Ragsdale et al. 2007), on plant growth, photosynthesis, and yield. We targeted the establishment and maintenance of four different categories of daily aphid populations on soybean plants, replicated among three caged plots and three noncaged plots: an aphid-free control group, and low ( $<50$ aphids per plant), medium (between 50-100 aphids per plant), and high population (greater than 100 aphids per plant) densities. Aphids were introduced onto plants on July 5, when plants were in the V4 stage. Soybean leaflets containing soybean aphids were destructively sampled from the field surrounding the study area. Then, 4 leaflets were placed in low treatment plots, 10 leaflets in medium treatments, and 30-60 in high treatments. Weekly, from July 5 through September 9, aphid counts were made by visually inspecting 10 full plants per plot to determine CAD in each plot. Occasionally, if aphid populations were higher than targeted in caged plots, lady beetles were placed in cages and the cage screen openings were unzipped for a period to allow an ambient level of natural enemies to gradually decrease the aphid population. By adding lady beetles and temporarily opening up cages to allow for natural suppression of aphid populations by ambient predators, it is possible that changes in aphid feeding behavior (in addition to density) may also have been momentarily affected, resulting in less feeding pressure than would be indicated by density alone (Nelson 2007). Thus, CADs in high treatments may be a slight overestimation of actual feeding pressure on soybean. CAD were calculated following Ruppel (1983). Open plots attained a range of CAD from approximately 300 to 5,000 (Table 1). Caged plots experienced two clusters of CAD, from 1,300 to 8,000 and greater than 120,000 (Table 1, Fig. 1) .

\section{Greenhouse Experiment}

In 2013, we conducted an experiment to manipulate populations of soybean aphids to attain a continuum of CAD values $(0-50,000)$ that were partially absent during the 2011 experiment; in particular, from 8,000 to 50,000 CAD. This experiment was conducted from May 28 to August 29 in a 3- by 4-m corner greenhouse room attached to the Biotron, a research glasshouse with temperature-regulated rooms located on the University of Wisconsin-Madison campus. The average daily temperature in the greenhouse was $24^{\circ} \mathrm{C}$, with a typical summer range from $17^{\circ} \mathrm{C}$ to $37^{\circ} \mathrm{C}$. Plants received ambient light in the greenhouse as well as supplemental light from high-powered sodium lamps with a 16:8 (L:D) h photoperiod. Lamps were in power-saving mode and were only in operation when light sensor readings fell below $5 \mathrm{~V}$ (approximately 50 percent of full sunlight). Renk 241NR2 (Renk Seeds, Sun Prairie, WI) untreated seeds were inoculated with Bradyrhizobium japonicum and planted on May 27. Seeds were planted in 6-liter black plastic pots using Metromix 300, a soilless potting medium consisting of vermiculite, bark, Canadian sphagnum peat moss, coarse perlite, bark ash, starter nutrient charge (with gypsum), slow-release N, and dolomitic limestone (Sun Gro Horticulture, Agawam, MA). Three seeds were planted in each of 24 pots on May 28, and thinned to the healthiest visible plant on June 21, when plants were in the development stage V2. Plants were arbitrarily repositioned once per week on three tables running the length of the room. Each table was covered with black landscape plastic to ensure that air conditioning vents at the bottom of the room did not cause an uneven airflow and temperature to plants. Plants were watered on alternating days with 0.5 liter of half-strength Hoagland solution until July 15, when they were watered with 1 liter of half-strength Hoagland solution to account for an increase in water loss attributed to increasing evapotranspiration.

\section{Aphid Manipulation}

We allocated soybean plants to two treatments (12 plants each) and introduced soybean aphids (mixture of field-collected and 1-yr-old laboratory colony) either during V2 growth (two fully expanded true trifoliates) or R0 (first flowers) phenological stages to test for differing responses of soybean plants that were initially populated during the vegetative and reproductive stages. Soybean plants were infested at V2 to simulate how an early season arrival of soybean aphids and prolonged exposure would affect plants, and R0 was chosen to simulate a later arrival of soybean aphids during the early reproductive stage. Because CAD can be allocated in many different ways and arrive at the same value (e.g., $10 \mathrm{~d}$ with 500 aphids per plant and $50 \mathrm{~d}$ with 100 aphids per plant both equal $5000 \mathrm{CAD}$ ), we used a numerical modeling approach to determine realistic daily population trajectories for our greenhouse soybean plants. This ensured that with careful aphid counting and physical manipulation of aphid populations, we would attain desired CAD values as well as mimic the $\mathrm{CAD}$ trajectories that are generally found in natural settings. Daily aphid population targets were determined using the following equation:

$$
N_{t}=N_{0} e^{r_{\max } t(1-(1 / 2) a t)}
$$

where $N_{t}$ is the aphid population at time $t$ (aphids/plant), $N_{o}$ is the initial number of aphids per plant, $t$ is time (days), $r_{\max }$ is the intrinsic rate of increase in aphids (aphids/aphid/day) at time $=0$, and $a$ is the slope of the linear relationship between the rate of growth and time (Costamagna et al. 2007). This model uses a decreasing rate of growth to best model aphid populations on soybean over the growing season. A range of end-of-season CAD were targeted for each treatment type (V2 and R0) with three replications of each: 0 CAD for control, 5,000 CAD for low, 8,000 CAD for medium, and 

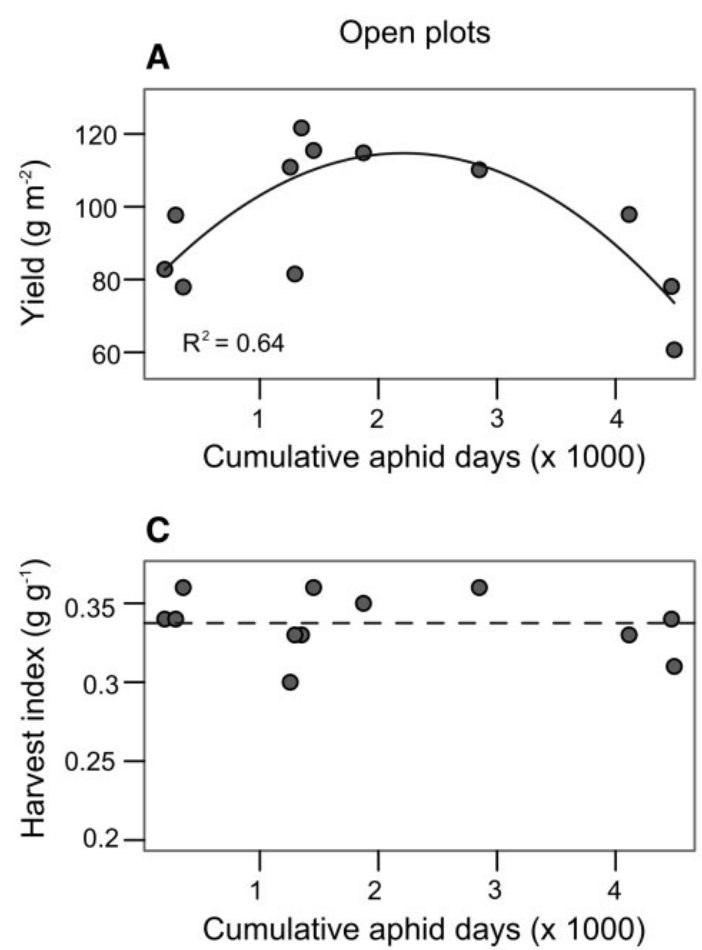

B Caged plots
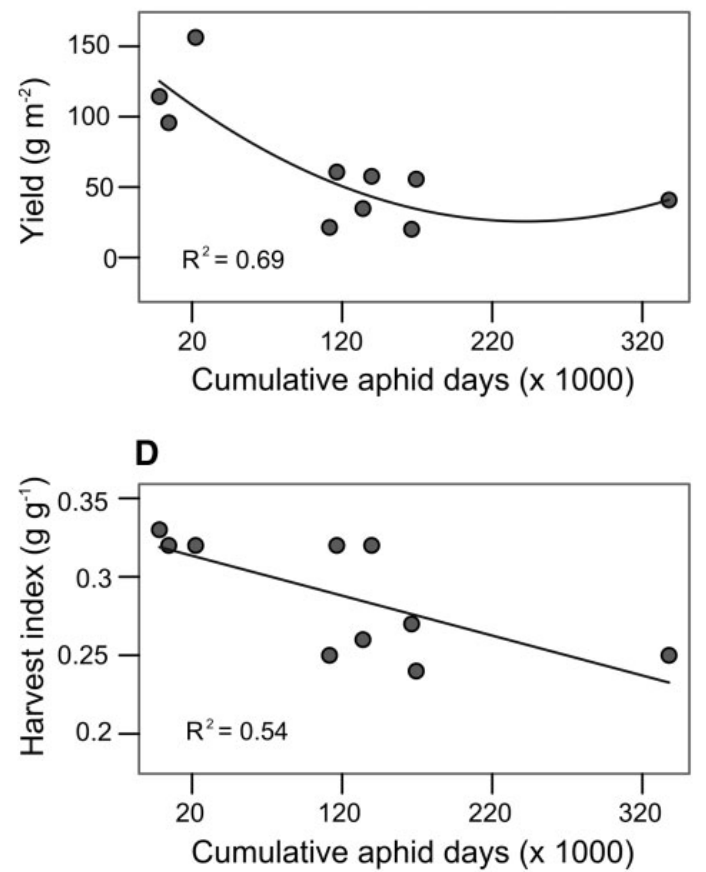

Fig. 1. For the 2011 field experiment, relationship between yield and CAD for (a) open field and (b) caged study plots. Relationship between harvest index and CAD for (c) open field and (d) caged study plots. Note y-axis scale is different between (a) and (b).

Table 1. Observed range of CAD, soybean yield, harvest index, ambient rate of photosynthesis at 400 ppm $\mathrm{CO}_{2}\left(\mathrm{~A}_{400}\right)$, and leaf percent nitrogen (N) for varied experimental treatments during 2011 and 2013

\begin{tabular}{llccrrr}
\hline Year & \multicolumn{1}{c}{ Treatment } & CAD range & $\begin{array}{c}\text { Yield range } \\
\left(\mathrm{g} \mathrm{m}^{-2}\right)\end{array}$ & $\begin{array}{c}\text { Harvest index } \\
\text { range }\end{array}$ & $\begin{array}{c}\text { A } 400 \text { range } \\
\left(\mu \mathrm{mol} \mathrm{m}^{-2} \mathrm{~s}^{-1}\right)\end{array}$ & $\begin{array}{c}\text { Leaf percent } \\
\mathrm{N} \mathrm{range}\end{array}$ \\
\hline 2011 & Open field plots & $296-4,592$ & $15.2-30.4$ & $0.30-0.36$ & $12.4-31.7$ & $2.4-4.8$ \\
& Insect cage enclosures & $1,398-340,849$ & $5.0-39.1$ & $0.24-0.33$ & $6.9-33.5$ & $2.5-4.7$ \\
2013 & Control plants & $252-1,113$ & $27.0-39.5$ & $0.15-0.20$ & $8.1-23.3$ & $2.3-4.6$ \\
& V2 aphid introduction & $7,812-20,125$ & $27.9-34.7$ & $0.16-0.27$ & $9.3-27.5$ & $3.0-4.5$ \\
& R0 aphid introduction & $9,537-50,222$ & $26.5-38.0$ & $0.15-0.25$ & $3.0-29.7$ \\
\hline
\end{tabular}

14,000 for high. Aphids were recorded on each full plant three times per week, with aphids added or removed as needed to bring populations to target levels. Aphids were randomly chosen from colony plants to be added to experimental plants; however, fully developed and reproducing aphids were targeted for removal from experimental plants to better regulate the population.

\section{Leaf Gas Exchange Measurements and Plant Harvest}

In both experiments, leaf gas exchange (photosynthesis) measurements were collected using a LI-6400XT portable photosynthesis system (LI-COR Inc., Lincoln, NE) coupled with a standard LED light (red/blue) source (model \#6400-02B) and $\mathrm{CO}_{2}$ injection system. Assimilation $(\mathrm{A})$ versus internal $\mathrm{CO}_{2}$ concentration $\left(\mathrm{C}_{\mathrm{i}}\right)$, otherwise known as $\mathrm{CO}_{2}$ or $\mathrm{A}-\mathrm{C}_{\mathrm{i}}$ response curves, and light response curves were performed on two upper-canopy, fully expanded trifoliate leaves for each plant or plot to ensure similar leaf age for the duration of the experiment. For $\mathrm{A}-\mathrm{C}_{\mathrm{i}}$ response curves, plants were illuminated with $2,000 \mu \mathrm{mol}$ quanta $\mathrm{m}^{-2} \mathrm{~s}^{-1}$ while $\mathrm{CO}_{2}$ concentration inside the leaf chamber ranged from $0 \mu \mathrm{mol} \mathrm{CO} \mathrm{Col}^{-1}$ to $1,000 \mu \mathrm{mol} \mathrm{CO} \mathrm{mol}^{-1}$. We stabilized at a reference of $400 \mu \mathrm{mol}$ $\mathrm{CO}_{2} \mathrm{~mol}^{-1}$ and followed standard practice (Bernacchi et al. 2013) decreasing $\mathrm{CO}_{2}$ to our minimum, followed by a return to $400 \mu \mathrm{mol}$
$\mathrm{CO}_{2} \mathrm{~mol}^{-1}$ before increasing to our maximum value of $1,000 \mu \mathrm{mol}$ $\mathrm{CO}_{2} \mathrm{~mol}^{-1}$. For light response curves, chamber $\mathrm{CO}_{2}$ concentration remained constant at $400 \mu \mathrm{mol} \mathrm{CO} \mathrm{Col}^{-1}$ and light intensity was decreased from 2,000 to $0 \mu \mathrm{mol}$ quanta $\mathrm{m}^{-2} \mathrm{~s}^{-1}$. All gas exchange measurements were collected between 09:00 and 17:00 local time. In 2011, gas exchange measurements were collected approximately weekly from August 2 through September 7 at leaf temperatures around $25^{\circ} \mathrm{C}$. At the time of these gas exchange measurements in 2011 , three replicates of $0-6 \mathrm{~cm}$ depth volumetric water content were taken in each plot with a Dynamax TH300 'Big Stick' Soil Moisture Probe (Dynamax, Houston, TX). In 2013, leaf gas exchange measurements were collected from June 24 through August 26 at ambient greenhouse temperatures, with leaf temperatures between 23 and $27^{\circ} \mathrm{C}$.

Plants were harvested in the R6 growth stage for both years (16 September 2011 and 30 August 2013). For both years, plants were cut at the soil surface and dried at $60^{\circ} \mathrm{C}$ for $48 \mathrm{~h}$. After drying, individual plant components (i.e., seed, pod, leaf, and stem) were hand-separated and weighed. Harvest index was calculated using the ratio of dry seed weight to total aboveground biomass. Soybean yield was defined as grams of dry seed weight on a square meter basis. 


\section{Leaf Nitrogen}

Foliar $\mathrm{N}$ content was estimated using in situ/in vivo reflectance spectroscopy on fresh, green leaves. For all plants measured in both 2011 $(n=24)$ and $2013(n=24)$, leaf reflectance spectra were collected from one upper and lower leaf selected at random using a full-range (400-2,500 nm, reflectance estimated at 1-nm intervals) portable spectroradiometer (ASD FieldSpec 3, Analytical Spectral Devices, Boulder, CO). Physical measurements were acquired using a leaf-clip consisting of a contact probe attached to a fiber optic and a calibrated light source. Leaf reflectance from the contact probe is determined relative to that of a $99 \%$ (white) Spectralon panel (Labsphere, Inc., North Sutton, NH). For each canopy position (upper and lower) leaf, we made five spectral measurements, which were averaged to generate one single spectrum per plant representing those two canopy locations. From those spectra, we applied an existing chemometric equation (partial least squares regression [PLSR]; Wold et al. 2001) to estimate $\mathrm{N}$ concentration by dry weight as a function of reflectance in each wavelength. Here we used wavelength-by-wavelength PLSR coefficients reported by Serbin et al. (2014).

\section{Statistical Analysis}

Statistical analyses were performed using the $\mathrm{R}$ software package version 3.1.1 (R Development Core Team 2014). We analyzed the effect of soybean aphid using total growing season CAD on yield and harvest index for caged and uncaged field plots, separately, in 2011. Separate analyses were necessary because our research showed that biophysical conditions that affect yield, such as light intensity and soil moisture, varied significantly between cages and open plots (Perillo et al. 2015), and because we did not have appropriate season-integrated measurements of light and moisture to use as covariates in the analysis. We used a general linear model to fit yield and harvest index as a function of linear and quadratic CAD terms to allow for nonlinear relationships between variables. For computational reasons, we centered CAD measurements before analysis. We tested the unique contributions of linear and quadratic CAD terms using marginal $F$-tests.

We analyzed the effect of CAD (up until the measurement) on 2011 photosynthesis rates using combined data from caged and uncaged field plots. We were able to conduct a combined analysis in this instance because we had comparable measurements of two important covariates, the $\mathrm{N}$ content of leaves and near surface soil moisture, that could be used to account for differences in biophysical conditions between caged versus uncaged plot types when instantaneous photosynthesis measurements were taken. Both leaf $\mathrm{N}$ and soil moisture estimates were taken within, at most, $3 \mathrm{~d}$ of photosynthesis measurements. As above, we modeled photosynthesis using linear and quadratic CAD terms to account for possible nonlinearity. We log-transformed CAD before analysis so that our estimates of CAD effects were not dominated by high (leverage) CAD measurements from caged plots. We centered log-transformed CAD measurements before statistical analysis for computational reasons. During analysis, it became apparent that the relationship between photosynthesis and leaf $\mathrm{N}$ was neither linear nor welldescribed by polynomial terms. Thus, we modeled photosynthesis using a generalized additive mixed-effects model, with parametric terms for CAD and soil moisture, and a smoothed term for leaf N. A mixed-effects model, with a random intercept per plot, was used to account for multiple measurements per experimental plot. The importance of parametric terms was assessed using $t$-tests, derived from slope estimates and standard errors, where degrees of freedom varied by term depending on its level in the mixed model. The importance of the $\mathrm{N}$ term was assessed using a marginal $F$-test with degrees of freedom based on the optimal flexibility of the smoother.

For 2013 greenhouse data, we used a general linear model to fit yield and harvest index as a function of total growing season CAD and the timing of aphid introduction. As before, we included a squared CAD term to account for nonlinearity, centered CAD measurements before analysis, and tested the importance of model terms using marginal F-tests. We modeled 2013 photosynthetic rates as a function of CAD (up until the measurement), $\mathrm{CAD}^{2}$, leaf $\mathrm{N}$, and aphid introduction time using a linear mixed-effects model with a random intercept per plant to account for multiple photosynthesis measurements per plant. As before, we centered CAD and leaf $\mathrm{N}$ measurements before statistical analysis, and tested the importance of model terms using marginal $F$-tests, where denominator degrees of freedom varied by term depending on its level in the mixed model. When hypothesis tests were used, $P<0.05$ was considered statistically significant, unless stated otherwise.

\section{Results}

\section{Soybean Yield and Harvest Index Versus CAD}

In 2011, the range in CAD measured within insect exclusion cages compared with open field plots was substantially different; specifically, higher aphid populations were created inside cages, given the exclusion of aphid natural enemies (e.g., lady beetles). Plants within the open field plots experienced a limited range in CAD from a few hundred to about 4,600 (Table 1), whereas the maximum CAD within cages exceeded 340,000 (Table 1). We conducted separate analyses to assess the response of yield to CAD for caged plots and open field plots. For the field plots, we found that the yield-CAD relationship was fit well by a parabola that peaked around the average CAD and then declined (Fig. 1a; whole model $R^{2}=0.64$; linear term $F=1.25, \mathrm{df}=1,9, P=0.2930 ;$ quadratic term $\mathrm{F}=14.11, \mathrm{df}=1,9$, $P=0.0045$ ). This model suggested that a positive yield increase occurred for CAD up to 2,300 CAD, with a subsequent decline for higher CAD (Fig. 1a). For caged plots, which experienced much higher CADs, this analysis indicated that yields declined as a function of increasing $\mathrm{CAD}$, whereby average yields were reduced by approximately 60 percent when CAD was greater than 100,000 (Fig. 1b; whole model $R^{2}=0.69$; linear term $F=15.32, \mathrm{df}=1,7$, $P=0.0058$; quadratic term $F=5.49, \mathrm{df}=1,7, P=0.0516)$. While this model showed a clear negative relationship between yield and increasing CAD, our data potentially suggest that the impact on yield may eventually reach a nonzero asymptote at very high CAD (Fig. 1b). However, we caution that this is based on only one plot of data at high CAD.

In open field plots during the 2011 experiment, there was no significant relationship between harvest index $(\mathrm{HI})$ and soybean aphids (Fig. 1c; whole model $R^{2}=0.07$; whole model $F=0.36, \mathrm{df}=2,9$, $P=0.7104)$. However, at the extremes of our data within the insect cages, where CAD reached greater than 300,000 in some plots, there was a trend toward a negative linear relationship between $\mathrm{HI}$ and CAD (Fig. 1d; whole model $R^{2}=0.53$; linear term $F=7.81, \mathrm{df}=1$, 7, $P=0.0267$; quadratic term $F=0.82, \mathrm{df}=1,7, P=0.3944)$. However, additional data would be necessary to confirm this trend to larger values of $\mathrm{CAD}$.

\section{Soybean Photosynthesis Versus CAD, Leaf N, and Soil Moisture}

For the 2011 field experiment, there was a clear, quadratic relationship between ambient soybean photosynthesis $\left(\mathrm{A}_{400}\right)$ and the log of 

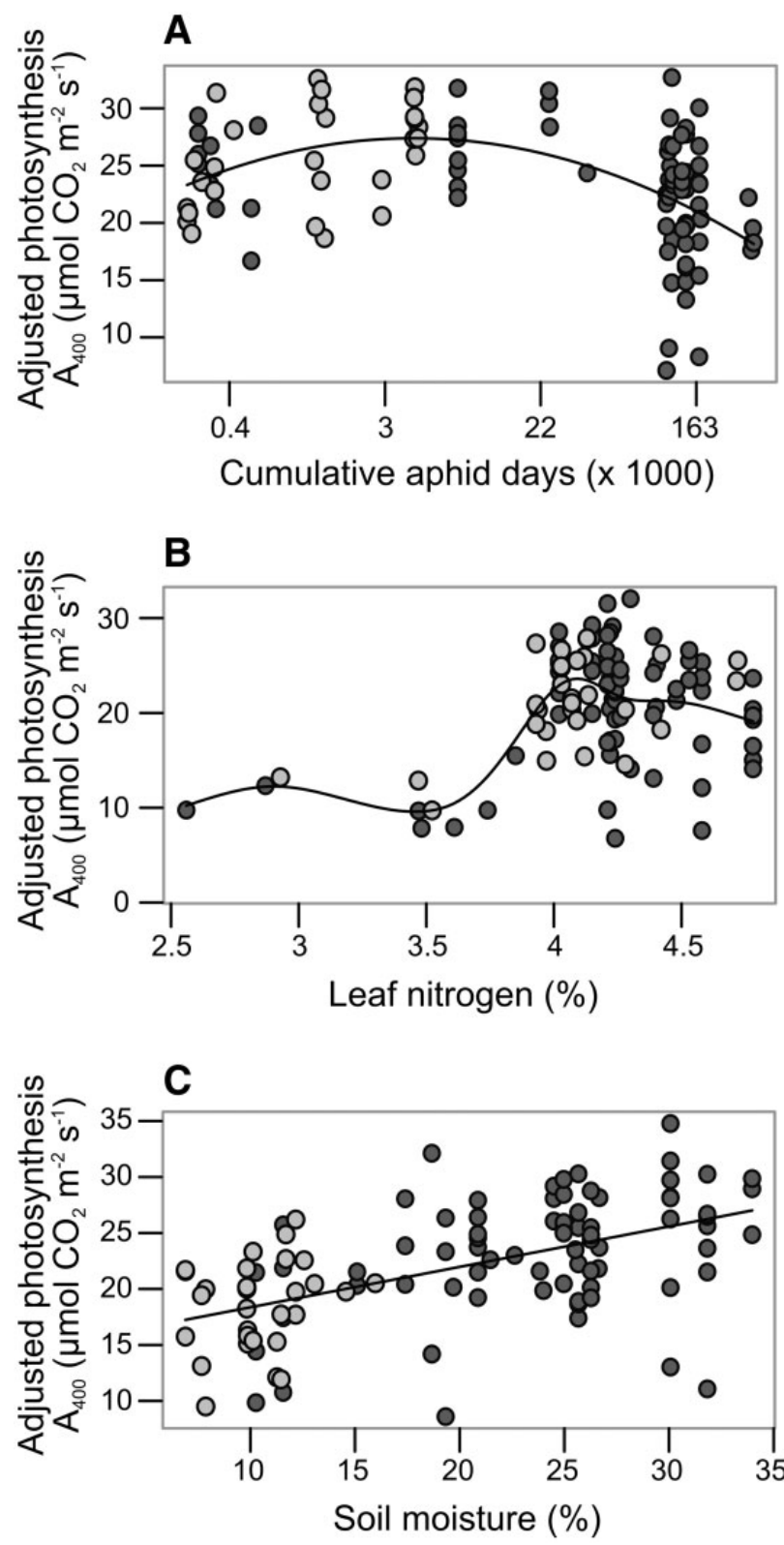

Fig. 2. For the 2011 field experiment, the relationship between photosynthesis ( $\mu \mathrm{mol} \mathrm{CO}_{2} \mathrm{~m}^{-2} \mathrm{~s}^{-1}$ ) at $2,000 \mu \mathrm{mol}$ quanta $\mathrm{m}^{-2} \mathrm{~s}^{-1}$ and $400 \mathrm{ppm} \mathrm{CO}_{2}\left(\mathrm{~A}_{400}\right)$ and (a) CAD (note log scale on $x$-axis), (b) leaf nitrogen (percent), and (c) volumetric soil moisture, expressed as a percentage. Light-shaded data points are from open field plots and darker shaded points are from plots with insect cages. In each panel, photosynthesis is adjusted for the partial effects of the two other variables.

CAD among all open field and caged plots (Fig. 2a; linear term $t=3.36, \mathrm{df}=82, P=0.0012$; quadratic term $t=3.12, \mathrm{df}=82$, $P=0.0025)$. There was also a nonlinear effect of leaf $\mathrm{N}$ concentration (Fig. 2b; smooth term $F=10.09, \mathrm{df}=4.3,97.7, P<0.0001$ ) and a clear positive linear effect of soil moisture (Fig. $2 \mathrm{c} ; t=3.41$, $\mathrm{df}=82, P=0.0010$ ) on ambient photosynthesis (whole model $\left.R^{2}=0.39\right)$. After accounting for CAD, surface soil moisture, and leaf $\mathrm{N}$ concentration differences across all plots and measurement days, ambient rates of photosynthesis were not different between open field and caged plants $(t=0.00, \mathrm{df}=18, P=0.9986)$. Leaf $\mathrm{N}$ values in 2011 decreased from approximately 4.4 percent at the R3 stage to 3.0 percent at the R6 stage (Fig. 3). Across all observations,

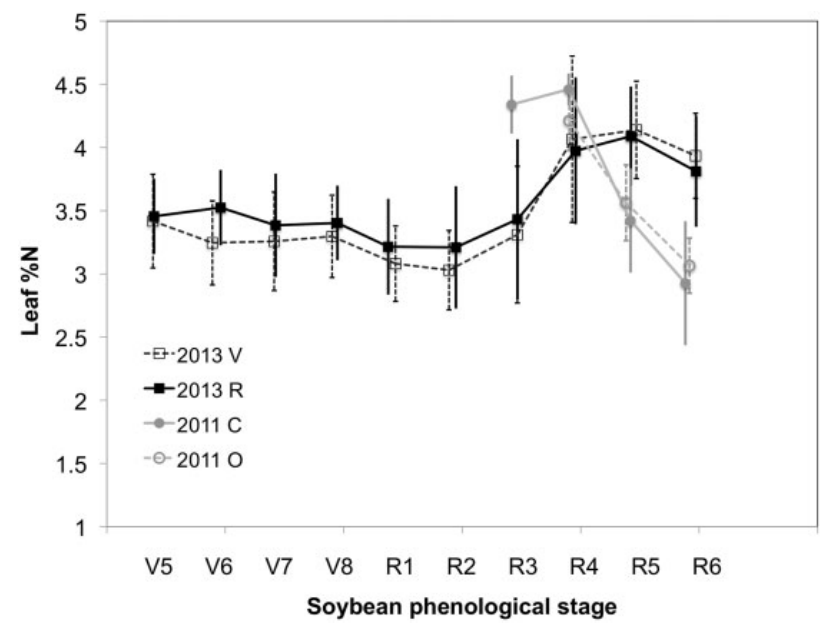

Fig. 3. Leaf nitrogen percentage versus soybean developmental stage for the field experiment in 2011 that consisted of open field plots $(2011,0)$ and caged plots (2011, C), and for the 2013 greenhouse experiment that had aphids introduced during the vegetative $(2013, \mathrm{~V})$ and reproductive $(2013, \mathrm{R})$ stages. Error bars denote $+/$ - one standard deviation. Data points were intentionally offset along the $\mathrm{x}$-axis using jittering to minimize overplotting.

there was no significant difference between leaf percent $\mathrm{N}$ values in open field (3.43 percent) and cage (3.47 percent) plots $(F=0.07$, $\mathrm{df}=1,93, P=0.7953)$. There was a significant difference between leaf percent $\mathrm{N}$ values in lower canopy (2.94 percent) and upper (3.60 percent) canopy positions $(F=18.69, \mathrm{df}=1,93, P<0.0001)$. When accounting for the effects of CAD and leaf $\mathrm{N}$, photosynthesis was approximately 50 percent higher at field capacity (33 percent volumetric water content) than near the permanent wilting point (13 percent; Fig. 2c).

\section{Soybean Yields and HI Versus CAD and Time of Introduction of Aphids}

In the 2013 greenhouse experiment, CAD ranged from near 0 (control plots) to 50,222 (Table 1), but there was no clear relationship between yield and CAD (Fig. $4 \mathrm{a} ; F=2.03, \mathrm{df}=1,20, P=0.1700$ ), and the timing of aphid introduction (at stages V2 vs. R0) also did not have a strong effect on yields $(F=1.99, \mathrm{df}=1,20, P=0.1737)$. However, we did find evidence for a possible weak parabolic relationship between $\mathrm{HI}$ and CAD (Fig. $4 \mathrm{~b}$; CAD $F=3.08, \mathrm{df}=1,20$, $\left.P=0.0946, \mathrm{CAD}^{2} F=4.66, \mathrm{df}=1,20, P=0.0431\right)$. Moreover, the timing of aphid introduction did not have a significant effect on $\mathrm{HI}$ differences among plots that had aphids introduced either at the V2 or the R0 development stage $(F=3.11, \mathrm{df}=1,20, P=0.0930)$.

\section{Soybean Photosynthesis Versus CAD, Leaf N, and Timing of Aphid Introduction}

In the 2013 greenhouse experiment, $\mathrm{A}_{400}$ rates strongly increased during the experiment as independent linear functions of CAD (Fig. 4c; $F=13.86, \mathrm{df}=1,59, P=0.0004$ ) and leaf $\mathrm{N}$ (Fig. 4d; $F=23.23, \mathrm{df}=1,59, P<0.0001)$. In contrast, the timing of aphid introduction did not have a significant effect on rates of ambient photosynthesis $(F=0.99, \mathrm{df}=1,25, P=0.3285)$. In 2013, leaf $\mathrm{N}$ was approximately 3.2-3.5 percent during V5 through R2 stages, and increased thereafter to 4.1 percent at development stage R5, and then slightly decreased to 3.9 percent by stage R6 (Fig. 3). Across all observations, there was no significant difference between leaf percent $\mathrm{N}$ values in plants that had aphids introduced at the $\mathrm{V} 2$ stage (3.56 percent) and R0 stage $(3.62$ percent; $F=2.55, \mathrm{df}=1$, 

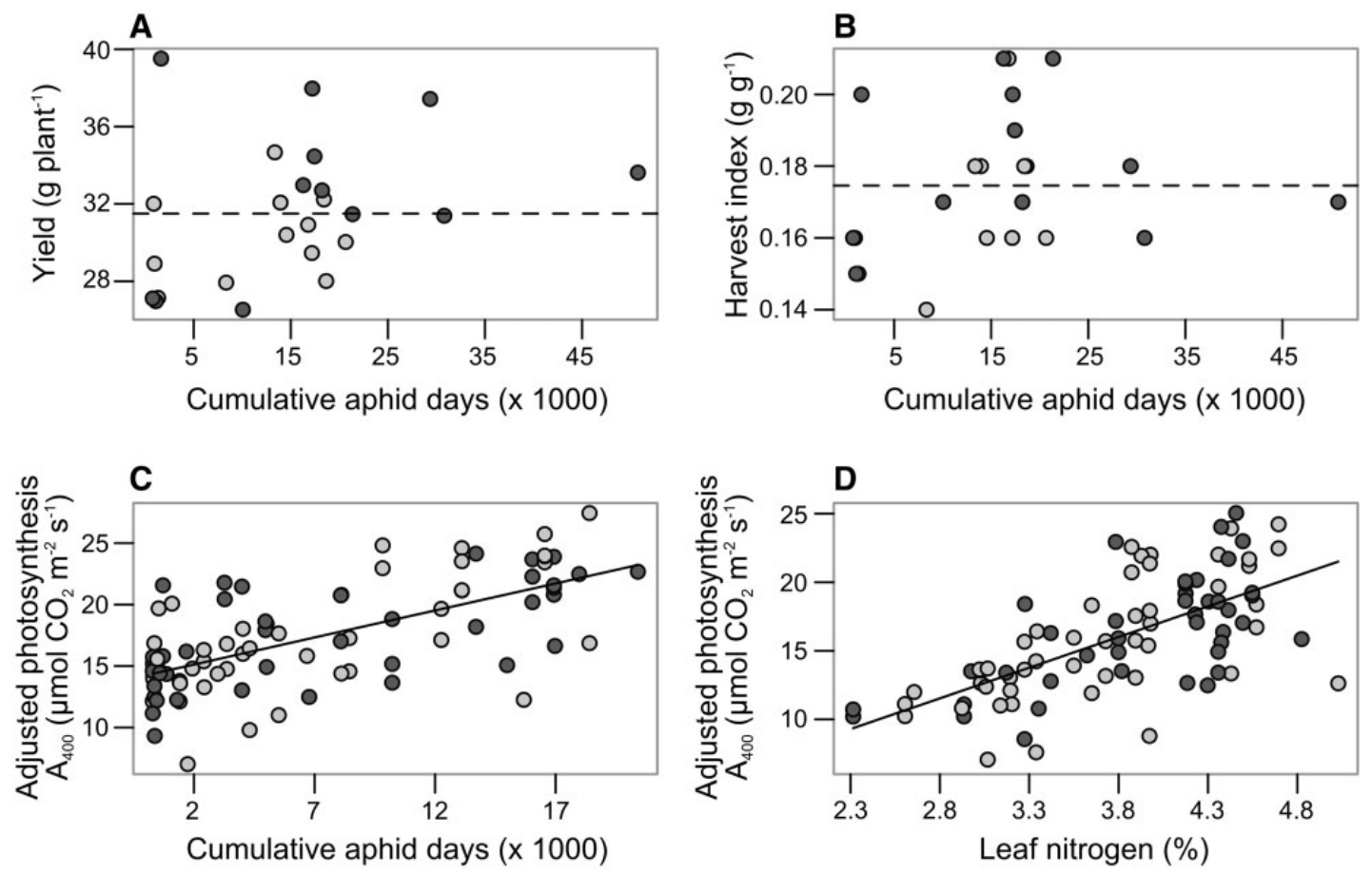

Fig. 4. For the 2013 greenhouse experiment, relationships between $C A D$ and ( $A$ ) yield and (B) harvest index, and the partial relationships between (C) $C A D$ and (D) leaf nitrogen (percent) and photosynthesis $\left(\mu \mathrm{mol} \mathrm{CO}_{2} \mathrm{~m}^{-2} \mathrm{~s}^{-1}\right)$. Light shaded data points are from plants that had aphids introduced at the $\mathrm{V} 2$ stage, and darker shaded points are from plants with aphids introduced at the R0 stage. In C and D, photosynthesis is adjusted for the partial effects of the other variable.

$1129, P=0.1104)$. There was a significant difference between leaf percent $\mathrm{N}$ values in lower canopy (3.46 percent) and upper canopy (3.71 percent) positions $(F=52.57, \mathrm{df}=1,1129, P<0.0001)$.

\section{Discussion}

\section{Soybean Yield in Natural Experiment Showed Compensatory Response at Low CAD, but 60 percent Yield Loss at High CAD}

Our field study suggested that low CAD might induce compensatory growth in soybean, which was also found in a recent study by Liere et al. (2015) for soybeans grown in Wisconsin and Michigan. Compensatory growth at low aphid pressure has been sparingly documented in the literature, likely because research has focused on much higher aphid populations, which pose significant risk to plants and economic yield (Ragsdale et al. 2007). A study measuring the effects of soybean aphid on plant growth and seed composition found some evidence of compensatory responses in plants infested with 600 aphids for $10 \mathrm{~d}(6,000 \mathrm{CAD})$ at either the V1 or V3 stage (Riedell and Catangui 2006). These infested plants had greater stem length and seed weight compared with aphid-free control plants (Riedell and Catangui 2006). However, aphid infested plants in that study were grown in a low blue light environment that might cause stem elongation in soybean (Wheeler et al. 1991, Riedell and Catangui 2006). Previous work also suggests a linear relationship exists between CAD and yield (Ragsdale et al. 2007) rather than the nonlinear (parabolic) response that we observed; however, an analysis of potential curvilinear patterns in yield response (e.g., Fig. 2 Ragsdale et al. 2007) may be warranted. Aphid populations in our open field plots never reached high levels, which was probably a consequence of natural predator populations (Rutledge et al. 2004, Costamagna and Landis 2006, Desneux et al. 2006, Donaldson et al. 2007, Costamagna et al. 2008) and not due to inherent aphid resistance. This is supported by our cage results, where the same soybean variety was planted and aphid populations grew well above the economic threshold (Table 1).

At high CAD, yield was significantly lower than control (no aphid) plants also grown in cages. Previous research suggested $\sim 7$ percent reduction in yield for each 10,000 CAD (Ragsdale et al. 2007). In comparison, we observed an approximate 60 percent decline in yields at 100,000 CAD, which, on average, would be about the same yield loss predicted by the Ragsdale et al. (2007) assessment. Plants with high aphid populations showed some visible symptoms of soybean aphid stress (stunted growth and sooty mold development) in addition to reduced yields. Compensatory growth and tolerance were not observed in the cages, likely because CAD in noncontrol plots ranged from 100,000 to 341,000 , well above the economic threshold $(10,000 \mathrm{CAD})$ where yield reductions are typically expected (Ragsdale et al. 2007, Beckendorf et al. 2008). We also reiterate that a confounding factor could be the fear of predators, whereby some plots may have experienced different per-aphid impacts on the plants.

During the 2011 field experiment, the quadratic relationship between photosynthesis $\left(\mathrm{A}_{400}\right)$ and $\log$ of CAD (Fig. 2a) followed the approximate yield response (Fig. 1a,b). The reduction in photosynthesis with high aphid pressure was expected, given previous research for both wheat and soybean aphids (Peterson and Higley 1993; Haile et al. 1999; Macedo et al. 2003, 2009; Diaz-Montano et al. 2007; Pierson et al. 2011). Aphids withdraw sap, which contributes to a reduction in normal phloem transport and reduces photosynthate and $\mathrm{N}$ transport (Peterson and Higley 1993, Pierson et al. 2011). Honeydew formation can also physically block stomatal openings, reducing conductance of water vapor out of the leaf and $\mathrm{CO}_{2}$ uptake into the leaf (Peterson and Higley 1993, Pierson et al. 2011). Other researchers have suggested that reductions in chlorophyll content and leaf area can lead to a reduction in 
photosynthetic efficiency (Riedell 1989, Miller et al. 1994, DiazMontano et al. 2007, Pierson et al. 2011). However, the compensatory yield response that was observed at low CADs (around 2,300) during 2011 was supported by photosynthetic rates that were slightly higher than the control plants. These data support a potential "overcompensation" response that is also associated with increased yields (Tiffin 2000, Poveda et al. 2010).

We also observed a rapid decrease in leaf $\mathrm{N}$ over the 2011 measurement period (Fig. 3), together with a threshold effect of leaf $\mathrm{N}$ on photosynthesis of around 3.5 percent (Fig. 2b). A decline in leaf $\mathrm{N}$ during the late reproductive stages (R5-R6) has been previously reported for soybean, as $\mathrm{N}$ is translocated from the leaves to the seeds (Boote et al. 1978, Lugg and Sinclair 1981, Boonlong et al. 1983) and as an overall decline in $\mathrm{N}_{2}$ fixation activity occurs (Salvagiotti et al. 2008). The positive, strong response of leaf photosynthesis to increasing leaf $\mathrm{N}$ per unit area has been well-documented for soybean as well as other agricultural cropping systems (Sinclair and Horie 1989, Lawlor 2002, Sinclair 2004, Salvagiotti et al. 2008).

\section{Controlled Greenhouse Study Showed no Yield Loss With Moderate to High CAD and Nonstressful Growing Conditions}

Our greenhouse experiment indicated that soybean aphid pressure well above the economic threshold (up to $\sim 50,000$ CAD) did not cause a reduction in soybean yield. This result was surprising given previous results, whereby about a 35 percent reduction in yield for this CAD level would have been expected (Ragsdale et al. 2007). Even though aphids covered stems, upper and lower canopy leaves, and petioles, leaving them sticky with honeydew by the end of the experiment, the leaves remained asymptomatic and the infested plants showed no signs of stunted growth compared with control plants. While this was in contrast to the 2011 caged results, the range of CAD in the greenhouse was much lower than the 2011 cage study, which likely contributed to the difference in plant visual appearances.

Comparing the response of yield with the timing of aphid introduction in 2013, we found that yield was not affected differently as a function of when aphids were introduced on plants. These findings are in contrast with other previously documented effects (Riedell and Catangui 2006, Beckendorf et al. 2008), and suggest that soybean aphid introduction during the early vegetative stages may simply lead to greater accumulation of CAD, which more directly controls the observed decline in yield.

In the 2013 greenhouse experiment, we observed a positive effect of soybean aphid pressure on $\mathrm{A}_{400}$ rates (Fig. 4c), even when CAD was well over the economic threshold of 10,000 . The majority of previous work has shown reductions in photosynthetic rates for a range of soybean aphid pressure (Pierson et al. 2011), and some reductions in photosynthesis are reported as much as 50 percent for populations of just 20 aphids leaflet ${ }^{-1}$ (Macedo et al. 2003). Moreover, previous work suggests that for CADs in the range we measured in 2013, a decline in mean photosynthesis is more likely to be observed than an increase (Haile et al. 1999; Macedo et al. 2003, 2009; Diaz-Montano et al. 2007; Pierson et al. 2011).

We concluded that the absence of an expected decline in leaf $\mathrm{N}$ in the 2013 greenhouse study during late development stages (R4R6) supported a positive, linear response with increasing CAD. Continuous use of Hoagland's solution to irrigate and fertilize plants with $\mathrm{N}$ were factors that likely allowed increasing $\mathrm{A}_{400}$ rates as a function of CAD (Fig. 4c). This use of fertilized water likely supplied enough $\mathrm{N}$ for the development of seeds without as large a reduction in leaf $\mathrm{N}$ as was observed in the 2011 field experiments; this also would have supported consistency or increases in $\mathrm{A}_{400}$ rates as the plants progressed through the reproductive stages, allowing them to be more tolerant of the detrimental effects of increased aphid feeding (Sinclair and Horie 1989, Sinclair 2004). However, we also emphasize that the CAD effect was positive throughout the range of aphids imposed in 2013, independent of leaf $\mathrm{N}$ content (Fig. 4c).

\section{Possible Pathways for Compensatory Growth and Tolerance}

In the study of plant-herbivore ecology, there has been a continual debate on whether plant tolerance to insect or other herbivore damage is controlled by the availability of key resources (Trumble et al. 1993; Wise and Abrahamson 2005, 2007). There are several possible explanations for the compensatory growth-and actually, potential overcompensation-that we observed in the field in 2011 and for the soybean aphid tolerance observed in the greenhouse in 2013. In the 2011 field experiment, aphid feeding potentially stimulated plants and caused increased photosynthesis and yield at lower aphid populations. This occurred at a time of moderate drought conditions, when during 3 of the $5 \mathrm{wk}$ that photosynthesis data were collected, surface soil moisture was below the permanent wilting point (Perillo et al. 2015). It has also been suggested that plant hormones, jasmonic acid and ethylene, might play a role in compensatory growth signaling in response to aphid-induced stress (Yang and Hoffman 1984, Creelman et al. 1992, Kessler and Baldwin 2002, Riedell and Catangui 2006, Goggin 2007).

In the greenhouse, plants were able to tolerate a higher population of aphids than what we likely would have seen in the field study, given an abundance of $\mathrm{N}$ available for uptake. Environmental conditions in the greenhouse also played a role in soybean plant tolerance to increased aphid feeding; because air temperature was regulated inside of the greenhouse, no temperature extremes over long periods were experienced, and irrigation prevented plant water stress, as was the case in the 2011 field experiment. While tolerance to soybean aphids has not been well-documented in lines that do not possess Rag1 and Rag2 genes in the soybean germplasm (Mian et al. 2008, Kim and Diers 2009), it was noted many decades ago that soybean can be tolerant to some amount of herbivory (Begum and Eden 1965, Thomas et al. 1974). Tolerance to defoliation is manifested through delayed reproductive stages and increased light interception and rates of photosynthesis (Haile et al. 1999). Resistance to defoliation was dependent on other environmental factors such as soil moisture and light interception. As well, tolerance to cotton aphid (Aphis gossypii Glover) and compensatory growth have been documented in pre-production cotton (Rosenheim et al. 1997).

In this study, we cannot definitively answer why increased aphid pressure above the economic threshold of 50,000 CAD in greenhouse conditions did not universally adversely affect $\mathrm{A}_{400}$ rates and yield. Soybean aphid populations have been shown to vary with plant N (Nowak and Komor 2010; Riedell et al. 2013a,b) and with plant responses that affect amino acid concentrations (Myers and Gratton 2006, Walter and DiFonzo 2007). A trend toward higher percent leaf $\mathrm{N}$ in late growth stages in greenhouse plants may have decreased the amount of time of aphid feeding and sap extraction while simultaneously supporting an increase in photosynthesis. Soybean aphids are N-limited (Walter and DiFonzo 2007), and increased $\mathrm{N}$ in the leaves may have supported a higher aphid population with reduced impacts on yields than what has been previously determined in field conditions for soybean experiencing typical 
nutrient management regimens. Further research will be needed to understand why we saw a positive effect of $\mathrm{CAD}$ on $\mathrm{A}_{400}$ rates, and to quantify at what level of aphid pressure is $\mathrm{A}_{400}$ reduced over a wider variety of environmental conditions, including soil nutrient levels.

In summary, our results suggested that, given widely varying growing conditions, soybean plants could tolerate low to intermediate populations of soybean aphids with no reduction in yield, much higher than has been previously documented. This research suggests that current economic thresholds for soybean aphid, although they may be appropriate on average, could be refined based on the context of specific growing environments. In a field experiment where soybeans experienced a moderately dry period during the reproductive stage, with surface soil moisture at or below permanent wilting point for 3 of $5 \mathrm{wk}$ in August and early September of 2011, soybean plants were still able to tolerate and even increase performance for a low level of aphid pressure (the response peaked at approximately 2,300 CAD, corresponding to $\sim 50$ aphids/plant at peak). In our follow-up 2013 greenhouse study, we observed no adverse impact on $\mathrm{A}_{400}$ rates or yields at moderate to high CAD ( 8,000 to 50,000), when previous research suggested that yields should have declined by up to 35 percent and should have been accompanied by a corresponding decrease in photosynthesis.

While it is unclear as to the exact mechanism by which plant compensation, or overcompensation, took place in 2011 to increase yields relative to control plots, plants in the greenhouse experiment most likely benefitted from continual delivery of $\mathrm{N}$ fertilizer in solution. This suggests that increased $\mathrm{N}$ availability to soybean for uptake could be a mechanism to help tolerate feeding damage caused by the soybean aphid. This is reasonable given the known relationships between photosynthesis and $\mathrm{N}$, and the fact that soybean aphids require $\mathrm{N}$. While it is confidently stated in the scientific literature that there is a consistent and positive relationship between photosynthesis and leaf $\mathrm{N}$ content per leaf area, it is less certain that increases in $\mathrm{N}$ fertilizer lead to increased yields (Salvagiotti et al. 2008). For soybean, this is because an excess of soil $\mathrm{N}$ available to plants can inhibit nodule formation, thereby reducing capacity to fix $\mathrm{N}$. This information, and results of our greenhouse experiment may suggest that an economic threshold for soybean aphid management may be a moving target that varies as a function of fertilizer management, nodule development, and $\mathrm{N}$ mineralization in soils, given that studies of the plant-herbivore relationship show that key resources, and their availability, exert a strong control on the actual tolerance of plants (Wise and Abrahamson 2007). A key question posed by Salvagiotti et al. (2008) is whether additional fertilizer N can help combat $\mathrm{N}$ limitations to soybean growth-without compromising or suppressing the development of nodules and capacity for $\mathrm{N}_{2}$ fixation. As well, if more $\mathrm{N}$ fertilizer is deemed necessary to optimize yields, is it economically viable to use? And, could a similar question be posed in the context of mitigating aphid impacts on yield? That is, could increased amounts of fertilizer added, or more fertile soils, have an advantage in helping soybean plants tolerate soybean aphid pressure that is well above the currently published threshold $(10,000$ CAD) where yield loss is assumed to occur? Given the close connection between soybean aphids, plant $\mathrm{N}$ uptake, yield potential, and photosynthetic capacity, we suggest that future research focus on understanding the relationship between the soybean $\mathrm{N}$ cycle, management regimens for pest control and soil health, and soil and environmental conditions that influence the economic threshold at which aphid damage begins to impact soybean profitability.

\section{Acknowledgments}

We thank the two anonymous reviewers for their thoroughness and helpful suggestions. We thank Molly Young, Jade Kochanski, Trip Hook, Clayton Kingdon, Skye Greenler, Mike Cruse, Joey Lechelt, Ryan Geygan, Rob Phetteplace, Nick Grout, and Tyler Davis for assisting with fieldwork. We appreciate the helpful discussions and input from Daniel Kleinman. The research was funded through USDA Agriculture and Food Research Initiative Competitive Grant \#2011-67009-3002. S.P.S. was partially supported by the United States Department of Energy contract No. DE-SC00112704 to Brookhaven National Laboratory.

\section{References Cited}

Beckendorf, E. A., M. A. Catangui, and W. E. Riedell. 2008. Soybean aphid feeding injury and soybean yield, yield components, and seed composition. Agron. J. 100: 237-246.

Begum, A., and W. G. Eden. 1965. Influence of defoliation on yield and quality of soybeans. J. Econ. Entomol. 58: 591-592.

Bernacchi, C. J., J. E. Bagley, S. P. Serbin, U. M. Ruiz-Vera, D. M. Rosenthal, and A. Vanloocke. 2013. Modelling C-3 photosynthesis from the chloroplast to the ecosystem. Plant Cell Environ. 36: 1641-1657.

Boonlong, P., D. B. Egli, and J. E. Leggett. 1983. Leaf-N and Photosynthesis during reproductive growth in soybeans. Crop Sci. 23: 617-620.

Boote, K. J., R. N. Gallaher, W. K. Robertson, K. Hinson, and L. C. Hammond. 1978. Effect of foliar fertilization on photosynthesis, leaf nutrition, and yield of soybeans. Agron. J. 70: 787-791.

Clark, A. J., and K. L. Perry. 2002. Transmissibility of field isolates of soybean viruses by Aphis glycines. Plant Dis. 86: 1219-1222.

Costamagna, A. C., and D. A. Landis. 2006. Predators exert top-down control of soybean aphid across a gradient of agricultural management systems. Ecol. Appl. 16: 1619-1628.

Costamagna, A. C., W. van der Werf, F. Bianchi, and D. A. Landis. 2007. An exponential growth model with decreasing r captures bottom-up effects on the population growth of Aphis glycines Matsumura (Hemiptera: Aphididae). Agric. For. Entomol. 9: 297-305.

Costamagna, A. C., D. A. Landis, and M. J. Brewer. 2008. The role of natural enemy guilds in Aphis glycines suppression. Biol. Control 45: 368-379.

Creelman, R. A., M. L. Tierney, and J. E. Mullet. 1992. Jasmonic acid methyl jasmonate accumulate in wounded soybean hypocotyls and modulate wound gene-expression. Proc. Natl. Acad. Sci. USA. 89: 4938-4941.

Davis, J. A., E. B. Radcliffe, and D. W. Ragsdale. 2005. Soybean aphid, Aphis glycines Matsumura, a new vector of Potato virus $\mathrm{Y}$ in potato. Am. J. Potato Res. 82: 197-201.

Desneux, N., R. J. O’Neil, and H.J.S. Yoo. 2006. Suppression of population growth of the soybean aphid, Aphis glycines Matsumura, by predators: The identification of a key predator and the effects of prey dispersion, predator abundance, and temperature. Environ. Entomol. 35: 1342-1349.

Diaz-Montano, J., J. C. Reese, W. T. Schapaugh, and L. R. Campbell. 2007. Chlorophyll loss caused by soybean aphid (Hemiptera: Aphididae) feeding on soybean. J. Econ. Entomol. 100: 1657-1662.

Donaldson, J. R., S. W. Myers, and C. Gratton. 2007. Density-dependent responses of soybean aphid (Aphis glycines Matsumura) populations to generalist predators in mid to late season soybean fields. Biol. Control 43: 111-118.

Fehr, W. R., C. E. Caviness, D. T. Burmood, and J. S. Penningt. 1971. Stage of development descriptions for soybeans, glycine-max (L) merrill. Crop Sci. 11: 929-931.

Goggin, F. L. 2007. Plant-aphid interactions: Molecular and ecological perspectives. Curr. Opin. Plant Biol. 10: 399-408.

Haile, F. J., R.K.D. Peterson, and L. G. Higley. 1999. Gas-exchange responses of alfalfa and soybean treated with insecticides. J. Econ. Entomol. 92: 954-959.

Hartman, G. L., E. D. West, and T. K. Herman. 2011. Crops that feed the World 2. Soybean-worldwide production, use, and constraints caused by pathogens and pests. Food Secur 3: 5-17. 
Kessler, A., and I. T. Baldwin. 2002. Plant responses to insect herbivory: The emerging molecular analysis. Annu. Rev. Plant Biol. 53: 299-328.

Kim, K. S., and B. W. Diers. 2009. The associated effects of the soybean aphid resistance locus rag1 on soybean yield and other agronomic traits. Crop Sci. 49: 1726-1732.

Kucharik, C. J. 2003. Evaluation of a process-based agro-ecosystem model (Agro-IBIS) across the US corn belt: Simulations of the interannual variability in maize yield. Earth Interact. 7.

Lawlor, D. W. 2002. Carbon and nitrogen assimilation in relation to yield: Mechanisms are the key to understanding production systems. J. Exp. Bot 53: 773-787.

Liere, H., T. N. Kim, B. P. Werling, T. D. Meehan, D. A. Landis, and C. Gratton. 2015. Trophic cascades in agricultural landscapes: indirect effects of landscape composition on crop yield. Ecol. Appl. 25: 652-661.

Lugg, D. G., and T. R. Sinclair. 1981. Seasonal-changes in photosynthesis of field-grown soybean leaflets .1. relation to leaflet dimensions. Photosynthetica 15: 129-137.

Macedo, T. B., C. S. Bastos, L. G. Higley, K. R. Ostlie, and S. Madhavan. 2003. Photosynthetic responses of soybean to soybean aphid (Homoptera: Aphididae) injury. J. Econ. Entomol. 96: 188-193.

Macedo, T. B., R.K.D. Peterson, D. K. Weaver, and X. Z. Ni. 2009. Impact of diuraphis noxia and rhopalosiphum padi (Hemiptera: Aphididae) on primary physiology of four near-isogenic wheat lines. J. Econ. Entomol. 102: 412-421.

McCarville, M. T., C. Kanobe, G. C. MacIntosh, and M. O'Neal. 2011. What is the economic threshold of soybean aphids (Hemiptera: Aphididae) in enemy-free space? J. Econ. Entomol. 104: 845-852.

Mian, M.A.R., R. B. Hammond, and S.K.S. Martin. 2008. New plant introductions with resistance to the soybean aphid. Crop Sci. 48: 1055-1061

Miller, H., D. R. Porter, J. D. Burd, D. W. Mornhinweg, and R. L. Burton. 1994. Physiological-effects of russian wheat aphid (Homoptera, Aphididae) on resistant and susceptible barley. J. Econ. Entomol. 87: 493-499.

Myers, S. W., and C. Gratton. 2006. Influence of potassium fertility on soybean aphid, Aphis glycines Matsumura (Hemiptera: Aphididae), population dynamics at a field and regional scale. Environ. Entomol. 35: 219-227.

Nelson, E. H. 2007. Predator avoidance behavior in the pea aphid: Costs, frequency, and population consequences. Oecologia 151: 22-32.

NOAA. 2011. Climatography of the United States No. 81, Monthly Station Normals of Temperature, Precipitation, and Heating and Cooling Degree Days 1981-2010: Wisconsin., United States Department of Commerce, National Climate Data Center. National Oceanic and Atmospheric Administration (NOAA), Asheville, NC.

Nowak, H., and E. Komor. 2010. How aphids decide what is good for them: Experiments to test aphid feeding behaviour on Tanacetum vulgare (L.) using different nitrogen regimes. Oecologia 163: 973-984.

Nowak, R. S., and M. M. Caldwell. 1984. A test of compensatory photosynthesis in the field - implications for herbivory tolerance. Oecologia 61: 311-318.

Perillo, A. C., C. J. Kucharik, T. D. Meehan, S. P. Serbin, A. Singh, P. A. Townsend, K. Stack Whitney, and C. Gratton. 2015. Use of insect exclusion cages in soybean creates an altered microclimate and differential crop response. Agric. For. Meteorol. 208: 50-61.

Peterson, R.K.D., and L. G. Higley. 1993. Arthropod injury and plant gas exchange: Current understandings and approaches for synthesis. Entomology 1: 93-100.

Pierson, L. M., T. M. Heng-Moss, T. E. Hunt, and J. C. Reese. 2010. Categorizing the resistance of soybean genotypes to the soybean aphid (Hemiptera: Aphididae). J. Econ. Entomol. 103: 1405-1411.

Pierson, L. M., T. M. Heng-Moss, T. E. Hunt, and J. Reese. 2011. Physiological responses of resistant and susceptible reproductive stage soybean to soybean aphid (Aphis glycines Matsumura) feeding. ArthropodPlant Inte 5: 49-58.
Poveda, K., M.I.G. Jimenez, and A. Kessler. 2010. The enemy as ally: Herbivore-induced increase in crop yield. Ecol. Appl. 20: 1787-1793.

Prochaska, T. J., L. M. Pierson, E.L.L. Baldin, T. E. Hunt, T. M. Heng-Moss, and J. C. Reese. 2013. Evaluation of late vegetative and reproductive stage soybeans for resistance to soybean aphid (Hemiptera: Aphididae). J. Econ. Entomol. 106: 1036-1044.

R Development Core Team 2014. R: A language and environment for statistical computing computer program, version By R Development Core Team, Vienna, Austria.

Ragsdale, D. W., D. J. Voegtlin, and R. J. O’Neil. 2004. Soybean aphid biology in North America. Ann. Entomol. Soc. Am. 97: 204-208.

Ragsdale, D. W., B. P. McCornack, R. C. Venette, B. D. Potter, I. V. Macrae, E. W. Hodgson, M. E. O’Neal, K. D. Johnson, R. J. O’Neil, C. D. Difonzo, et al. 2007. Economic threshold for soybean aphid (Hemiptera: Aphididae). J. Econ. Entomol. 100: 1258-1267.

Rhainds, M., M. Roy, G. Daigle, and J. Brodeur. 2007. Toward management guidelines for the soybean aphid in Quebec. I. Feeding damage in relationship to seasonality of infestation and incidence of native predators. Can. Entomol. 139: 728-741.

Riedell, W. E. 1989. Effects of Russian wheat aphid infestation on barley plant-response to drought stress. Physiol. Plantarum 77: 587-592.

Riedell, W. E., and M. A. Catangui. 2006. Greenhouse studies of soybean aphid (Hemiptera: Aphididae) effects on plant growth, seed yield and composition. J. Agric. Urban Entomol. 23: 225-235.

Riedell, W. E., E. A. Beckendorf, and M. A. Catangui. 2013a. Soybean aphid injury effects on shoot nitrogen components in glycine max. Crop Sci. 53: 232-239.

Riedell, W. E., E. A. Beckendorf, and M. A. Catangui. 2013b. Relationships between soybean shoot nitrogen components and soybean aphid populations. Arthropod Plant Inte 7: 667-676.

Rosenheim, J. A., L. R. Wilhoit, P. B. Goodell, E. E. GraftonCardwell, and T. F. Leigh. 1997. Plant compensation, natural biological control, and herbivory by Aphis gossypii on pre-reproductive cotton: the anatomy of a nonpest. Entomol. Exp. Appl. 85: 45-63.

Ruppel, R. F. 1983. Cumulative insect-days as an index of crop protection. J. Econ. Entomol. 76: 375-377.

Rutledge, C. E., R. J. O’Neil, T. B. Fox, and D. A. Landis. 2004. Soybean aphid predators and their use in integrated pest management. Ann. Entomol. Soc. Am. 97: 240-248.

Salvagiotti, F., K. G. Cassman, J. E. Specht, D. T. Walters, A. Weiss, and A. Dobermann. 2008. Nitrogen uptake, fixation and response to fertilizer $\mathrm{N}$ in soybeans: A review. Field Crop Res. 108: 1-13.

Serbin, S. P., A. Singh, B. E. McNeil, C. C. Kingdon, and P. A. Townsend. 2014. Spectroscopic determination of leaf morphological and biochemical traits for northern temperate and boreal tree species. Ecol. Appl. 24: 1651-1669.

Sinclair, T. R. 2004. Improved carbon and nitrogen assimilation for increased yield, pp. 537-568. In H. R. Boerma and J. E. Specht (eds.), Soybeans: improvement, production, and uses. ASA, CSSA, SSSA, Madison, Wisconsin.

Sinclair, T. R., and T. Horie. 1989. Leaf nitrogen, photosynthesis, and crop radiation use efficiency - a review. Crop Sci. 29: 90-98.

Thomas, G. D., C. M. Ignoffo, K. D. Biever, and D. B. Smith. 1974. Influence of defoliation and depodding on yield of soybeans. J. Econ. Entomol. 67: 683-685.

Tiffin, P. 2000. Mechanisms of tolerance to herbivore damage: What do we know? Evol. Ecol. 14: 523-536.

Trumble, J. T., D. M. Kolodnyhirsch, and I. P. Ting. 1993. Plant compensation for arthropod herbivory. Annu. Rev. Entomol. 38: 93-119.

Venette, R. C., and D. W. Ragsdale. 2004. Assessing the invasion by soybean aphid (Homoptera: Aphididae): Where will it end? Ann. Entomol. Soc. Am. 97: 219-226.

Walter, A. J., and C. D. DiFonzo. 2007. Soil potassium deficiency affects soybean phloem nitrogen and soybean aphid populations. Environ. Entomol. 36: $26-33$. 
Wheeler, R. M., C. L. Mackowiak, and J. C. Sager. 1991. Soybean stem growth under high-pressure sodium with supplemental blue lighting. Agron. J. 83: 903-906.

Wilson, A.C.C., L.D.L. Sternberg, and K. B. Hurley. 2011. Aphids alter host-plant nitrogen isotope fractionation. Proc. Natl. Acad. Sci. USA. 108: 10220-10224.

Wise, M. J., and W. G. Abrahamson. 2005. Beyond the compensatory continuum: Environmental resource levels and plant tolerance of herbivory. Oikos 109: 417-428.
Wise, M. J., and W. G. Abrahamson. 2007. Effects of resource availability on tolerance of herbivory: A review and assessment of three opposing models. Am. Nat. 169: 443-454.

Wold, S., M. Sjostrom, and L. Eriksson. 2001. PLS-regression: A basic tool of chemometrics. Chemometr. Intell. Lab. Syst. 58: 109-130.

Yang, S. F., and N. E. Hoffman. 1984. Ethylene biosynthesis and its regulation in higher-plants. Annu. Rev. Plant Phys. 35: $155-189$. 